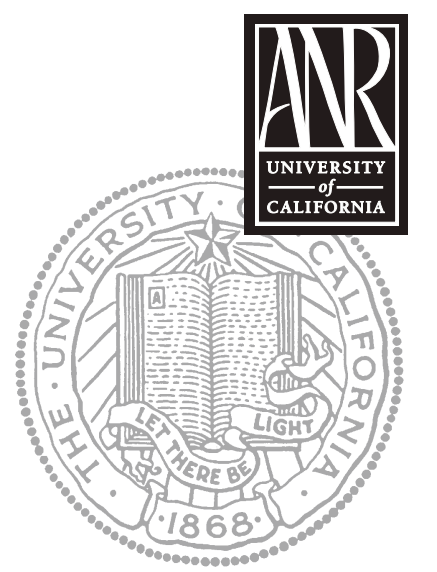

UNIVERSITY OF CALIFORNIA

Division of Agriculture and Natural Resources http://anrcatalog.ucdavis.edu
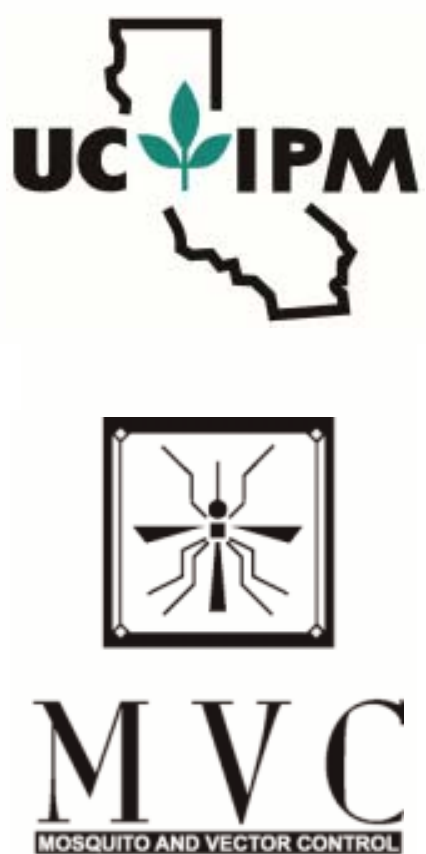

A S S OCIATION Of CALIFORNIA

\title{
Managing Mosquitoes in Surface-Flow Constructed Treatment Wetlands
}

WILLIAM E. WALTON, Associate Professor and Associate Entomologist, Department of Entomology, University of California, Riverside

Constructed treatment wetlands can provide cost-effective water quality treatment and may provide other benefits such as wildlife conservation, wetland habitat enhancement, and sites for public education and recreation. However, man-made wetlands used to treat municipal or agricultural wastewater as well as storm water often produce mosquitoes, which are a public health concern. Design features that are thought to be necessary for water quality improvement, such as shallow water and dense emergent vegetation, can cause significant mosquito production. Because many bird species are reservoirs for viral pathogens that cause diseases in humans and domesticated animals, the attraction of large numbers of birds to constructed wetlands also increases the risk of transmission of mosquito-borne viral infections to susceptible bird populations living near human residences and to humans and companion animals. The potential for conflict between wetland operators or managers and agencies charged with protecting public health is typically highest near areas of residential development and in arid regions where mosquito populations are naturally low.

This publication discusses how the design and operation of surface-flow wetlands constructed primarily for water quality improvement can contribute to issues related to high populations of mosquitoes. Subsurface-flow wetlands, another type of constructed treatment wetland, are not discussed here. Surface-flow wetlands most often appear similar to a marsh containing emergent vegetation (fig. 1). Many of the recommendations discussed here also apply to man-made wetlands intended for uses other than water quality improvement. Incorporating design features to minimize mosquito production can significantly decrease mosquito abundance, lower the costs of mosquito control, and may lessen legal liability.

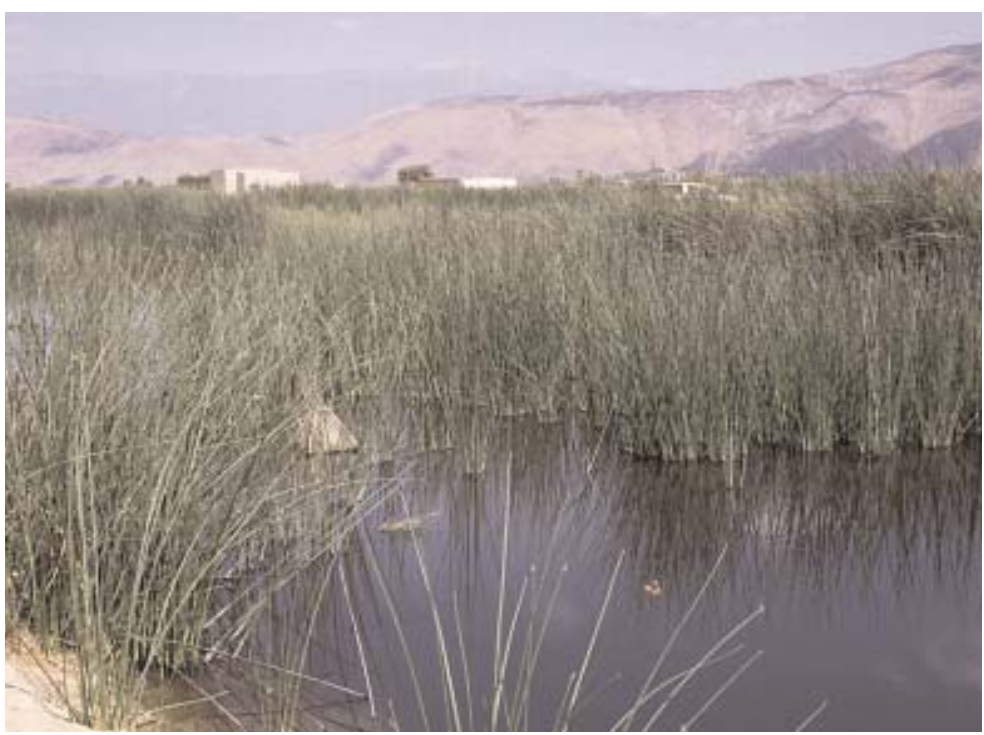

Figure 1. A constructed treatment wetland incorporating a mixture of emergent macrophytes in shallow marshes and deep-water zones. Photo: William E. Walton. 


\section{TREATMENT WETLAND SITING}

Most treatment wetlands must be built near the wastewater source because conveyance of wastewater and storm water over long distances is expensive and impractical. Several excellent publications listed in the bibliography highlight the factors to be considered when siting a wetland and describe the engineering principles that should be considered in the design of a wetland for water quality improvement.

Surrounding land uses and the potential for mosquitoes to move from a wetland into residential and commercial zones must be considered when siting a wetland. A conflict will be created over time if suburban sprawl encroaches on treatment wetlands in rural areas. Also, the area circumscribed by a wetland underestimates the potential region affected by mosquitoes because adult mosquitoes effectively disperse up to several miles from their developmental sites.

Buffer zones between human developments and adjacent mosquito habitation sites have been recommended by public health officials outside the United States to extend 1 to $1 \frac{1 / 4}{4}$ miles ( 1.5 to $2 \mathrm{~km}$ ), but larger buffer zones of 3 miles ( $5 \mathrm{~km}$ ) or more may be needed in situations where resident mosquito species disperse readily. Strong prevailing winds can move swarms of biting adult mosquitoes up to 10 miles (16 km). Active mosquito abatement is generally carried out within a 1-mile radius of a human

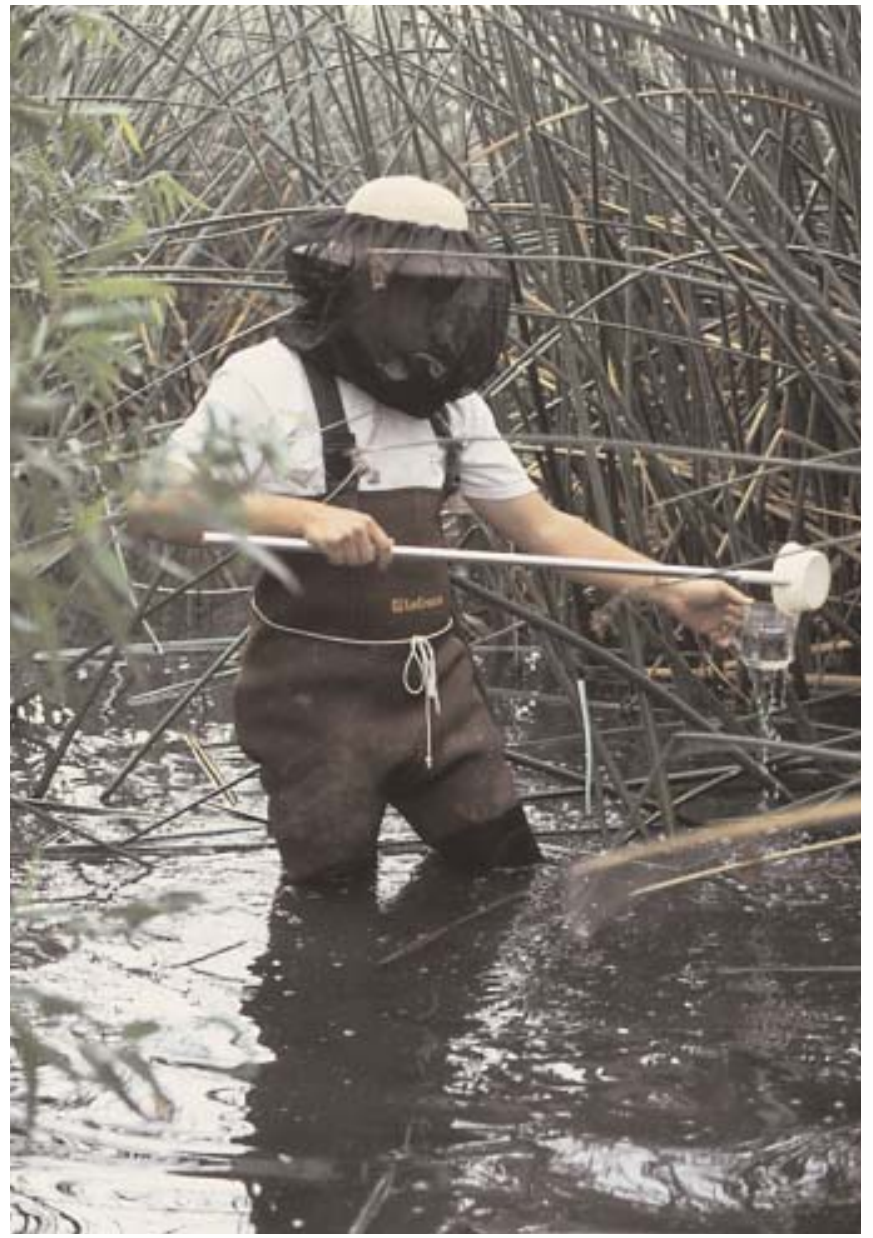

Figure 2. A technician samples mosquitoes in a constructed treatment wetland using a dipper. The dipper is similar to a ladle and holds 12 to 15 ounces (350 to $450 \mathrm{ml}$ ) of water. Dipping is a standard sampling technique for immature mosquitoes. This technician is using a head shield and DEET-based repellent on his shirt and arms to help avoid mosquito bites while sampling during a period of high mosquito production in the summer. Photo: William E. Walton. residential area if active sites of mosquito production are nearby. There is currently no established criterion in California for determining the size of a buffer zone around a treatment wetland. Typical distances reached by 90 percent of the mosquitoes emerging from a freshwater treatment wetland might range from $1 / 2$ to 3 miles ( 1 to $5 \mathrm{~km}$ ), but a buffer zone of this size may not be sufficient to avoid legal abatement.

\section{PRETREATMENT TO MINIMIZE MOSQUITO PRODUCTION}

Poor water quality tends to increase the production of mosquitoes. High levels of organic matter and nutrients, particularly reduced forms of nitrogen such as ammonia, are thought to provide nutrients for the bacteria and algae used as food by mosquito larvae. The decomposition of organic matter and conversion of ammonium to other forms of nitrogen in the nitrogen cycle require considerable amounts of oxygen, which can lead to low dissolved oxygen concentration and can create unsuitable conditions for aquatic mosquito predators such as predatory insects and fish.

Wastewater may require pretreatment before discharge into a treatment wetland, and the level of pretreatment is an important consideration in the size of a treatment wetland. Studies to date indicate that discharge of raw or primary-treated municipal wastewaters into a vegetated lagoon or shallow vegetated wetland can result in mosquito larval abundance from several hundred to over 1,000 larvae per 400-milliliter dip sample (fig. 2). Pretreatment to secondary standards may limit average densities to fewer than 200 mosquito larvae per sample (fig. 3), but these levels far exceed 


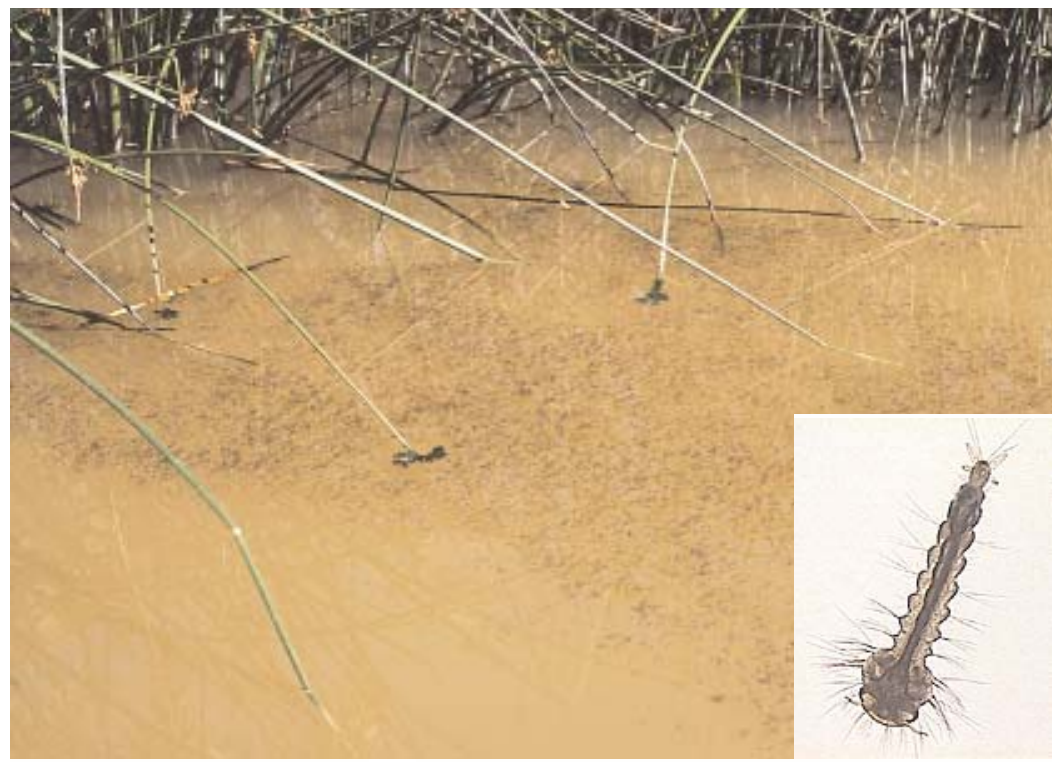

Figure 3. An aggregation of foul water mosquitoes (Culex quinquefasciatus and Culex stigmatosoma) near the outflow of secondary-treated sewage entering a constructed treatment wetland. The western encephalitis mosquito (Culex tarsalis) and tule mosquito (Culex erythrothorax) are prevalent within the vegetation. Insert: Close-up of a mosquito larva. Photos: William E. Walton. acceptable mosquito abundance, particularly when humans live nearby. Where threshold values for intervention against mosquitoes are in place for seasonally flooded and treatment wetlands, they range from average densities as low as 0.2 to 0.5 mosquito larvae (Culex and other species) per dip sample to 5 mosquito larvae per dip sample.

Although pretreatment before discharge into a treatment wetland may reduce mosquito production, it does not guarantee against mosquito presence.

\section{TREATMENT WETLAND DESIGN AND OPERATION}

\section{Wetland Cell Layout}

Compartmentalization of a wetland reduces mosquito abatement and wetland maintenance and management costs. By focusing mosquito abatement efforts on a comparatively small portion of the wetland and incorporating design features that facilitate effective mosquito control from the perimeter of the wetland (fig. 4), the cost of mosquito abatement decreases significantly as compared to mosquito abatement using fixed-wing aircraft or helicopters to dispense mosquito control agents across the entire wetland. In the southwestern United States, the cost in 1998 for applying mosquito control agents was $\$ 2,100$ to $\$ 2,700$ per acre per season for a 15 - to 25 -acre (6- to 10 -ha) thickly vegetated, single-basin wetland receiving municipal wastewater that had undergone secondary treatment (Walton 2002). (These costs were based on contractual agreements for commercial pest control services; surveillance is not included.) Costs can be significantly reduced when aircraft are not needed and mosquito abatement can be focused in compartmentalized wetlands receiving high-quality municipal effluent. For example, the cost of mosquito

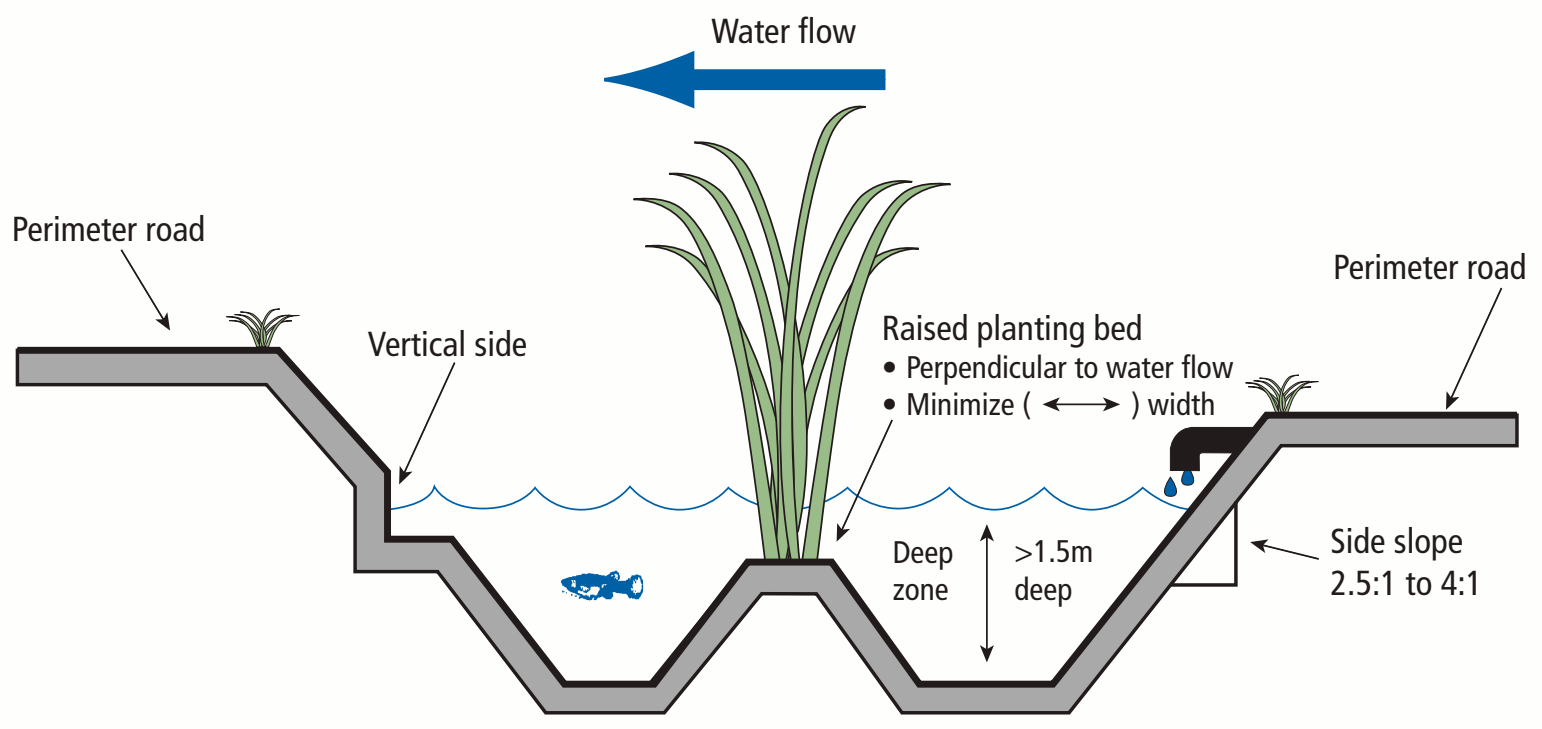

Figure 4. Cross-section of a constructed treatment wetland incorporating features that reduce mosquito production. Alternative designs for perimeter berms are illustrated. Note: drawing is not to scale. 
abatement for a compartmentalized 490-acre (198-ha) treatment wetland in 2000 was approximately $\$ 25$ per acre per season.

The maximum distance across the wetland cell surface should not exceed two times the effective distance of standard truck-mounted mosquito abatement equipment (about 20 feet $[6 \mathrm{~m}]$ ). Mosquito abatement for wetland cells that are larger than 40 feet $(12 \mathrm{~m})$ with roads on both sides may require special equipment and extra labor, which quickly increase the cost of mosquito control.

The costs of land, berm construction, water conveyance structures, and other features required to compartmentalize wetlands must be weighed against lower potential costs for maintenance and management as well as for mosquito abatement. A minimum of two parallel wetland cells is required to continue water treatment when one cell is removed from operation. Increased redundancy of water flow through a greater number of parallel flow paths enhances operational flexibility but may also significantly increase land and construction costs. Wetland cells may also be arranged in series for tiered designs on hillsides or to ensure and enhance water treatment when high-quality outflow is required. Combinations of parallel and series flow regimes, as well as blending incoming water with water recycled from the wetland effluent, can enhance water treatment and improve the flexibility of the flow regime.

\section{Water Depth and Flow Rate}

Shallow water (less than 6 inches $[15 \mathrm{~cm}]$ deep), thick vegetation, and poor water quality (e.g., high biological oxygen demand, high concentration of reduced forms of nitrogen) are virtually guaranteed to create mosquito problems. Water depths over 12 inches $(30 \mathrm{~cm})$ can reduce the health and growth of emergent plants in treatment wetlands and discourage mosquito production. However, based on limited experimental evidence, the deeper water also may be less effective in wetland treatment performance. Overall, water depths more than 3 to 4 feet ( 1 to $1.2 \mathrm{~m}$ ) may be required to reduce the proliferation of emergent vegetation and create conditions that effectively limit mosquito production.

Water deeper than 5 feet $(1.5 \mathrm{~m})$ (see fig. 4) is often recommended for limited areas of treatment wetlands because deep water zones

- help maintain plug flow by mixing and redistributing water flowing from shallow emergent marsh areas where short-circuiting may occur

- enhance wind-driven oxygenation of water, which is important when treating poor-quality water with high oxygen demands

- limit the area in the wetland colonized by emergent vegetation

- provide a sump for particulate matter

- create conditions that are less conducive for mosquito production.

Waves and water disturbance in open water zones are not favorable to mosquito egg laying and can drown immature mosquitoes. Open water zones also enhance predation by fish and other fauna on mosquito larvae and pupae. Nevertheless, treatment wetlands containing nearly complete surface coverage by vegetation and shallow water are still being proposed despite ample evidence of greater mosquito control problems, generally poor water quality performance, and comparatively lower wildlife value as compared to wetlands with mixed water depths and 50 percent, or less, emergent vegetation coverage.

For water quality improvement, water depth is an important aspect of treatment wetland design because it affects plant growth, diffusion distance, and hydraulic residence time. Water depths over about 2 feet $(60 \mathrm{~cm})$ cause pond or shallow lagoon conditions, which are not favorable for some water treatment needs and do not provide all of the treatment benefits of emergent vegetation in wetlands. Shallow water depths may increase linear flow velocities and shorten diffusion gradients, which is 
important for atmospheric or sediment exchange of gaseous and dissolved pollutants as well as substances such as atmospheric oxygen, but these benefits are lessened in zones of thick vegetation. The dissolved oxygen concentration in thick vegetation is typically very low (approximately $0 \mathrm{mg} / \mathrm{liter}$ ). Redox reactions favor mobilization of nutrients and other pollutants, and while low oxygen concentrations promote nutrient removal via denitrification they also promote mosquito production by reducing the effectiveness of mosquito predators. Moreover, shallow water (less than 6 inches [15 cm] deep) may cause incomplete flooding of wetland cells that have not been graded to precise elevation tolerances.

Whereas high flow velocities are known to reduce mosquito survival, a quantitative relationship between flow velocity and mosquito production does not currently exist. Mosquito production can occur from nearly any quiescent body of water, such as backwaters, more or less isolated pools, and marshy areas of streams and rivers.

\section{Wetland Grading and Bottom Slopes}

A bottom slope of 0.01 to 0.05 percent is recommended for wetlands if dewatering is needed for vegetation management and mosquito abatement. Bottom slopes must permit effective drainage yet not expose substrate to mosquito oviposition during operational fluctuations in water level or disrupt the maintenance of a consistent water depth. Constructed treatment wetland cells can be graded to small tolerances in elevation (variation as low as 1.2 inches $[3 \mathrm{~cm}]$ ) using laserleveling, whereas typical grading practices may provide variation within 6 inches $(15 \mathrm{~cm})$ of design specifications. Bottom slopes of 0.01 to 0.03 percent have been recommended for mosquito source reduction in irrigated agriculture. Bottom slopes in treatment wetlands typically range from 0 to about 0.5 percent.

\section{Wetland Side Slopes}

For mosquito control, steep embankments from 2.5:1 to 4:1 (horizontal:vertical; see fig. 4) adjacent to deep water are more effective than edges of shallow water containing extensive emergent vegetation. Steep slopes reduce the amount of emergent vegetation coverage, allow better access to immature mosquitoes by aquatic predators, and favor environmental factors such as wave action that decrease mosquito survival. Steep sides also limit the amount of wetted substrate favorable for oviposition by floodwater mosquitoes that is created by operational fluctuations in water level. The aspect ratios of side slopes should be compatible with mowing, levee maintenance, and safety concerns. Furthermore, the side slopes of levees and berms should adequately support movement of vehicles used for mosquito control along the top of the levee. While steeper side slopes cost less to construct than do shallow slope berms because steep slopes require a smaller volume of earth, steep slopes may be prone to erosion by wave action and slumping prior to establishment of groundcover.

If gently sloping embankments or peripheral vegetated zones are needed to fulfill one or more goals for wetland use, the area potentially colonized by emergent vegetation should be minimized. Side slopes of 5:1 to 10:1 encourage thick emergent vegetation that lessens the effectiveness of mosquito abatement. Peripheral vegetation zones should be restricted to narrow widths (less than 3 feet $[1 \mathrm{~m}]$ ) or should be designed to meet the minimum needs of wildlife under consideration.

\section{Hydrological Control}

Design features and operational procedures that effectively spread and move water throughout the wetland are important for both water treatment and mosquito control. Maintenance of water conveyance structures and the ability to drain sections or the entire wetland for maintenance and emergency situations is needed. If places in the wetland cannot be drained completely, mosquito control and wetland maintenance 
will be compromised. Wetland managers should know the period required for complete draining and assure that valves, weirs, and other structures necessary to move water and set water depth are properly maintained. A plan for emergency draining should be developed that addresses questions such as: Where will the water be put? Are pumps required? Are permits required to discharge the water from the wetland?

An ability to change the water level can be an important feature for mosquito control in wetlands that support submerged vegetation. Occasionally raising water levels above submerged macrophytes exposes mosquito larvae to predators.

\section{Vegetation Selection to Minimize Mosquito Production}

The emergent macrophytes commonly planted in man-made wetlands have been associated with high levels of mosquito production. Even though cattails (Typha spp.), bulrushes (Schoenoplectus [= Scirpus] spp.), and common reed (Phragmites australis) have been classified as less-desirable macrophytes for nontidal wetlands, there is currently no one plant species that is highly recommended for fulfilling the multiple functions of wetland vegetation (see Collins and Resh 1989). Dense stands of emergent plants are thought to be important for the water quality performance of wetlands, but the species composition of the wetland plant community appears to be less important than the density and net biomass production of the plants. In addition to being implicated in encouraging mosquito production, dense stands of emergent vegetation reduce the effectiveness of mosquito control agents by inhibiting the penetration of aerial or water-based applications of standard larval mosquito control agents.

\section{Plant Harvesting and Removal}

Vegetation management is generally expensive; incorporating wetland design features that minimize vegetation coverage is more effective than routine plant harvesting and removal. Mechanical harvesting and controlled burning are two practices commonly considered for vegetation management in treatment wetlands. Mechanical harvesting has been recommended instead of burning when vegetation management is needed; but in 1998, for example, vegetation removal by mechanical harvesting cost as much as $\$ 5,000$ to $\$ 7,000$ per acre (Walton 2002). In addition to the costs associated with removing and disposing of harvested plant biomass, the mechanical equipment needed to harvest dried macrophytes is very disruptive to treatment wetlands. The drying of wetland soils and movement of heavy equipment for harvesting disrupts organically rich wetland soils and can cause the export of significant quantities of accumulated pollutants from a treatment wetland following vegetation management.

Removing vegetation from shallow basins gives at best a short-term reduction of thick vegetative coverage in treatment wetlands, and it has been shown in some recent studies (Jiannino 2001; Thullen et al. 2002) to be ineffective for reducing mosquito populations as well. Plant regrowth rapidly replaces harvested vegetation. The reduction of macrophyte rhizome density in the substrate after burning does not offer significant benefits for long-term vegetation reduction over burning alone. Mosquito populations, particularly Culex species, are enhanced by the drying and disturbance of wetland substrates associated with vegetation removal. The short-term benefit for reducing mosquito production provided by reduced vegetation coverage is often overridden by relatively greater mosquito production from habitats where vegetation was partially removed. Reducing vegetation density can have a positive effect on mosquitofish (Gambusia affinis) density and mosquito control; however, design features that restrict emergent vegetation growth to small areas are thought to provide a comparatively more effective solution for reducing mosquito production.

Inundation of dried vegetation that has been knocked down by heavy equipment is thought to enhance wetland performance, but this management strategy is con- 


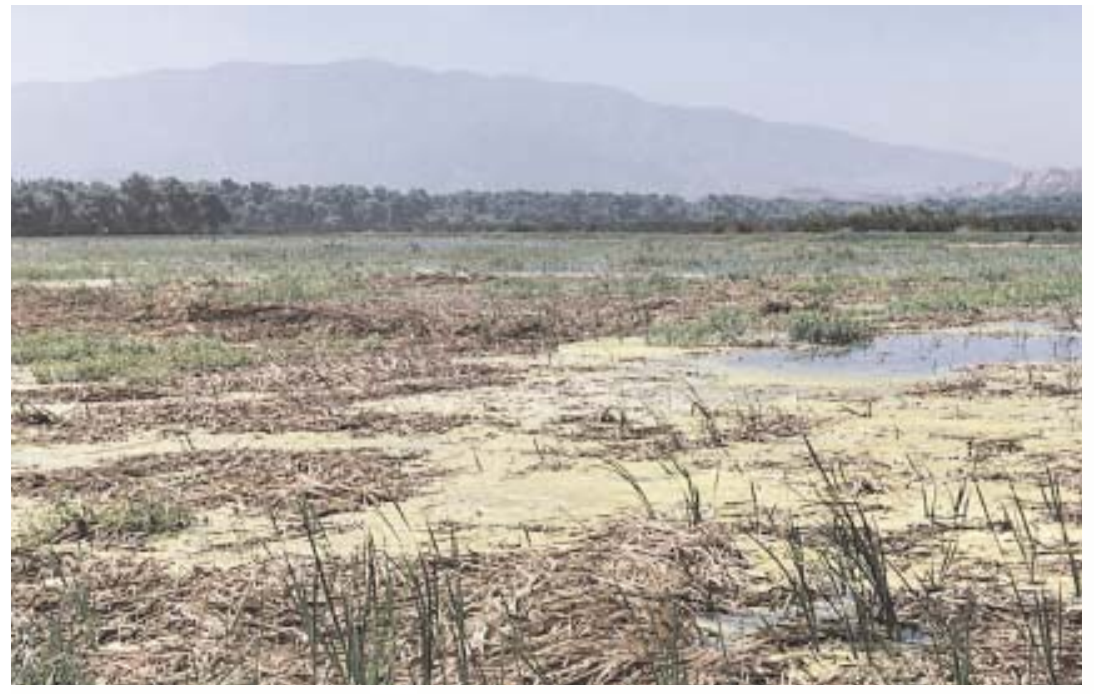

Figure 5. Emergent vegetation (cattails, Typha spp.) in a constructed treatment wetland. The cattails have been knocked down using heavy equipment, dried, and inundated. Although this management strategy is thought to enhance the bacterial populations responsible for water quality improvement, it caused significant levels of mosquito production that required multiple applications of mosquito control agents for nearly 2 months after reflooding. Photo: Joe B. Keiper.

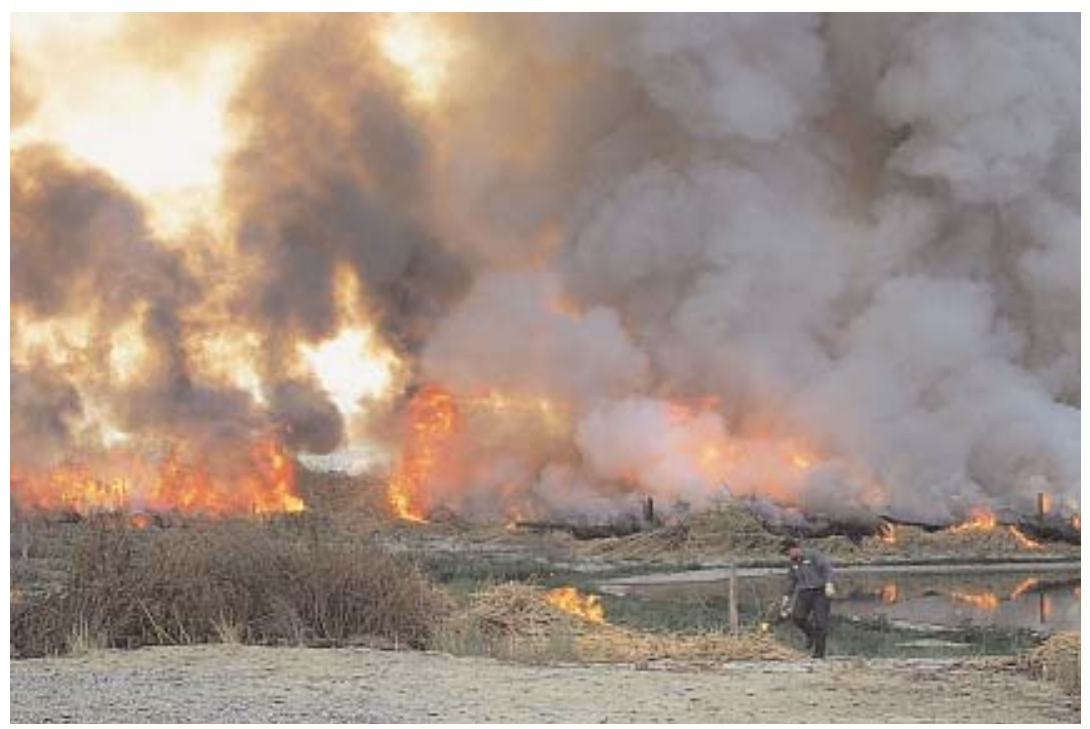

Figure 6. A controlled burn to remove dried emergent vegetation from a constructed treatment wetland. Controlled burns offer substantial cost savings when compared to harvesting and removing emergent vegetation, but they have drawbacks such as air quality concerns, extensive permitting, public relations costs, and delayed start-up because of poor postburn water quality. Photo: William E. Walton. traindicated for mosquito control and should be discouraged (fig. 5). The rationale for this management approach is that pollutant transformation and removal processes such as aquatic microbial transformation and burial rely on high rates of reduced carbon in the form of detritus from dead plant biomass. Yet too much dead plant biomass may decrease wetland water quality. Even in treatment wetlands that produce comparatively few mosquitoes per unit area, mosquito production is significantly enhanced after this form of vegetation management, and control measures are required for more than 6 weeks after reflooding.

Plant removal by controlled burning is an alternative to mechanical harvesting (fig. 6). Like mechanical harvesting, the entire wetland or portion of the wetland to be burned will be out of service while the vegetation is thoroughly dried. Controlled burning requires extensive permitting and coordination with multiple agencies (e.g., fire control, air quality management, federal and state agencies responsible for discharge pollutants), as well as providing information to residences and businesses that are likely to be affected by the smoke and particulate fallout from burns.

While no quantitative data have been published on the effect of fire management on the performance of treatment wetlands, burning is thought to mobilize nutrients stored in the plants, and inundating plant ash can result in a temporary slug of pollutants unless the flow-through operation is postponed long enough ( 1 or more months) for particulate pollutants to settle. During the period that this nutrientrich water is held in the wetland basin, mosquito production may increase and control measures may be required.

\section{Incorporation of Plant-free Zones}

For mosquito abatement, incorporating deep-water plant-free zones (see fig. 4) is more effective than either maintaining 100 percent of the wetland area in shallow water containing a dense growth of emergent macrophytes (shallow marshes), or routine harvesting of vegetation that involves drying of the wetland basin. If the latter strategy is used, harvested plant biomass should be removed from the basin before reflooding. Using raised planting beds may provide one approach to limiting emergent vegetation to narrow zones. 
Wetlands comprised only of shallow-water marshes are generally no longer recommended by wetland designers. For wetlands used primarily for water quality improvement, designs commonly incorporate deep-water zones that are at least 3 feet $(1 \mathrm{~m})$ deeper than the surrounding cell bottom elevation and that are limited to less than 25 percent of the entire wetland surface area. However, a further increase in deep-water zones (to nearly 80 percent of the wetland surface) is being tested in wetlands where water treatment has high oxygen demands.

In multipurpose treatment wetlands that also include wildlife habitat as a goal, a hemi-marsh configuration- 50 percent covered by vegetation, with deep zones making up 50 percent of the entire wetland area-follows wildlife managers' recommendations for managed wetlands. Islands are often constructed within the deep zones to increase the wetland-upland edge and to create refuges for nesting birds. Because of the potential for outbreaks of avian diseases, particularly during the hot summer period, there is no consensus among wetland managers as to the suitability of treatment wetlands as habitat for endangered waterbird species.

While deep-water zones generally reduce mosquito production from wetlands, colonization of deep-water zones by floating and submerged plants can occasionally create mosquito problems and may require significant vegetation management efforts. Floating plants such as duckweed (Lemna spp.) and water fern (Azolla spp.) may colonize open water zones that are protected from the prevailing wind. A complete coverage of the water surface by either plant can inhibit mosquito production; however, heavy mosquito production can occur within inevitable breaks in a surface mat. Submerged aquatic plants, particularly plants that create hiding places for mosquito larvae in highly dissected leaves, also may become established in deep zones. Significant management efforts and costs may be required to eliminate this plant growth.

Although at this time, no recommendation for limiting the width of plant zones can be supported by data, in one study, increasing the proportion of open water in small treatment wetlands (10,400 square feet [about $0.1 \mathrm{ha}$ ]) reduced total mosquito production and increased mortality of mosquito larvae (Walton and Workman 1998). However, plant zones 16 or 32 feet ( 5 or $10 \mathrm{~m}$ ) wide did not significantly reduce total wetland mosquito production as compared to fully vegetated wetlands (Jiannino 2001). Collins and Resh (1989) reported that plant zones might need to be limited to as little as 3 feet $(1 \mathrm{~m})$ wide to provide effective fish access for mosquito predation. Limiting emergent vegetation to raised planting beds may maintain narrow plant zones (Thullen et al. 2002); however, the practicality and efficacy of this approach for large wetlands has not been determined.

\section{Design for Biological and Chemical Control of Mosquito Populations}

Maintaining low rates of mosquito production is likely to depend on periodic use of mosquito control agents. Control measures against the stages of the mosquito life cycle that occur in water are preferred to control measures directed against adult mosquitoes. After mosquitoes become adults capable of dispersing from the wetland, mosquito control becomes more difficult, costly, and requires use of insecticide across a comparatively broad geographic area. Even though the insecticides currently used to control adult mosquitoes are safe, this method of control is not universally accepted by the general public because of perceived negative impacts. Furthermore, there are no effective biological control agents for adult mosquitoes. Despite popular beliefs, mosquitoes form only a very small component of the diets of birds and bats, and adults of most mosquito species are not active during the peak daily feeding period of many purported mosquito predators such as adult dragonflies.

Mosquito-specific control measures for immature mosquitoes are available but 
their effectiveness declines in thick vegetation and with poor water quality. In shallow, standing water, mosquito-specific microbial insecticides can be effective for longer than 1 week; however, dilution of mosquito control agents can be significant in treatment wetlands that have short water residence times. Biological control using fish and naturally occurring insect predators is enhanced by limiting the number of dense stands of emergent vegetation.

\section{RECOMMENDATIONS FOR ENHANCING MOSQUITO ABATEMENT EFFORTS IN CONSTRUCTED WETLANDS}

- Incorporate wide embankments to allow drivable shoreline access to all wetland cells. Access should have adequate turning areas. If cells exceed approximately 20 feet $(6 \mathrm{~m})$ wide, vehicular access to both sides must be provided. These embankments should have a top width of no less than 13 feet $(4 \mathrm{~m})$ and should have side slopes no steeper than 4:1 to allow access for mowing and sampling.

- Incorporate deep-water zones that are free of emergent and aquatic plants. Nearly vertical edges at the perimeter of the wetland limit the growth of emergent vegetation but may pose a safety concern.

- Provide access structures with appropriate slopes to cross deep-water zones. Boats or amphibious vehicles can be launched into these zones for application of mosquito control agents.

- Keep embankments and all wetland areas free of power lines, trees, and other tall vegetation and obstructions that might limit aerial spraying.

- Limit the width of emergent plant zones to facilitate access by predaceous fish and for application of chemical control agents.

- Compartmentalize the wetland so that the maximum width of ponds does not exceed two times the effective distance (40 feet [12 m]) of land-based application technologies for mosquito control agents. This design feature should reduce the costs of mosquito abatement by focusing mosquito abatement on small regions of the wetland and eliminating the need to apply mosquito control agents by aircraft.

- Minimize fluctuations in water level to prevent large areas of intermittently flooded substrate or isolated pools from being created, particularly during the period of annual mosquito activity (April to November in most regions of California).

- Budget for periodic vegetation maintenance and vector control.

- Have an emergency plan that provides for immediate drainage into acceptable areas if a public health emergency occurs.

\section{CONCLUSION}

Operating a wetland represents a long-term commitment to wetland maintenance and mosquito control and also exposes the managing organization to potential legal liability. The decision to proceed with wetland construction should be made after considering the technical, regulatory, and economic factors, as well as long-term plans for vegetation maintenance and vector control.

Regardless of how a manager attains responsibility for stewardship of a wetlandbuilding a wetland, assuming responsibility for an existing wetland, participating in a program to enhance wetland habitat, or assuming ownership of a shared wetland or land containing a wetland-as long as the wetland contains water, managers are legally responsible under the California Health and Safety Code for the costs of mosquito control or abatement of a public nuisance created by other organisms associated with that wetland. 


\section{BIBLIOGRAPHY}

California Health and Safety Code. See Division 3, Chapter 1, Articles 4 and 5 at http://www.leginfo.ca.gov/cgi-bin/calawquery? codesection=hsc\& codebody $=\&$ hits $=20$.

CH2M Hill. 1999. A mosquito control strategy for the Tres Rios Demonstration constructed wetlands. City of Phoenix, Water Services Department. Tempe, AZ: CH2M Hill.

Collins, J. N., and V. H. Resh. 1989. Guidelines for the ecological control of mosquitoes in non-tidal wetlands of the San Francisco Bay Area. Sacramento: California Mosquito Vector Control Association, Inc., and University of California Mosquito Research Program.

International Water Association. 2000. Constructed wetlands for pollution control: Processes, performance, design, and operation. IWA Specialist Group on Use of Macrophytes in Water Pollution Control Scientific and Technical Report No. 8. London, UK: IWA Publishing.

Jiannino, J. A. 2001. Evaluation of mosquito control strategies in a Southern California constructed treatment wetland. MS thesis. University of California, Riverside, Department of Entomology.

Kadlec, R. H., and R. L. Knight. 1996. Treatment wetlands. Boca Raton, FL: CRC/Lewis.

Metzger, M. E., D. F. Messer, C. L. Beitia, C. M. Myers, and V. L. Kramer. 2002. The dark side of stormwater runoff management: Disease vectors associated with structural BMPs. Stormwater 3(2):24-39.

Meyer, R. 1992. Residential encroachment on wetlands. Proceedings of the California Mosquito Vector Control Association 60:17-20.

Mulhern, T. D., ed. 1980. A training manual for California mosquito control agencies. California Department of Health, Vector and Waste Management Section. Visalia: CMCA Press.

Reed, S. C., R. W. Crites, and E. J. Middlebrooks. 1995. Natural systems for waste management and treatment. New York: McGraw-Hill.

Russell, R. C. 1999. Constructed wetlands and mosquitoes: Health hazards and management options-An Australian perspective. Ecological Engineering 12:107-124.

Sacramento-Yolo Mosquito Abatement District. 1992. Wetland development and management guidelines for the control of mosquitoes. Elk Grove, CA: SacYolo Mosquito Abatement District.

Schueler, T. R. 1992. Design of stormwater wetland systems: Guidelines for creating diverse and effective stormwater wetlands in the Mid-Atlantic Region. Washington, DC: Metropolitan Washington Council of Governments.

Thullen, J. S., J. J. Sartoris, and W. E. Walton. 2002. Effects of vegetation management in constructed wetland treatment cells on water quality and mosquito production. Ecological Engineering 18:441-457.

Vymazal, J., H. Brix, P. F. Cooper, M. B. Green, and R. Haberl, eds. 1998. Constructed wetlands for wastewater treatment in Europe. Leiden, The Netherlands: Backhuys Publishers.

Walton, W. E. 2002. Multipurpose constructed treatment wetlands in the arid southwestern United States: Are the benefits worth the risks? In J. Pries, ed., Treatment wetlands for water quality improvement: Quebec 2000 conference proceedings. Waterloo, ON: Pandora Press. 115-123. 
Walton, W. E., and P. D. Workman. 1998. Effect of marsh design on the abundance of mosquitoes in experimental constructed wetlands in Southern California. Journal of the American Mosquito Control Association 14:95-107.

\section{FOR MORE INFORMATION}

You'll find more information on mosquito control in these publications from UC ANR:

Aquatic Pest Control, Publication 3337, 2001.

Mosquitoes: Pest Notes for Home and Landscape, Publication 7451, 1998.

Available for free downloading from the ANR CS Web site at http://anrcatalog.ucdavis.edu.

Mosquitoes of California, 3rd edition, Publication 4084, 1978.

To order these publications, visit our online catalog at http://anrcatalog.ucdavis.edu. You can also place orders by mail, phone, or FAX, or request a printed catalog of publications, slide sets, videos, and CD-ROMs from

University of California

Agriculture and Natural Resources

Communication Services

6701 San Pablo Avenue, 2nd Floor

Oakland, California 94608-1239

Telephone: (800) 994-8849 or (510) 642-2431, FAX: (510) 643-5470

E-mail inquiries: danrcs@ucdavis.edu

An electronic version of this publication is available on the ANR Communication Services Web site at http://anrcatalog.ucdavis.edu.

Publication 8117

(C) 2003 by the Regents of the University of California, Division of Agriculture and Natural Resources. All rights reserved.

The University of California prohibits discrimination against or harassment of any person employed by or seeking employment with the University on the basis of race, color, national origin, religion, sex, physical or mental disability, medical condition (cancer-related or genetic characteristics), ancestry, marital status, age, sexual orientation, citizenship, or status as a covered veteran (special disabled veteran, Vietnam-era veteran or any other veteran who served on active duty during a war or in a campaign or expedition for which a campaign badge has been authorized).

University Policy is intended to be consistent with the provisions of applicable State and Federal laws.

Inquiries regarding the University's nondiscrimination policies may be directed to the Affirmative Action/Staff Personnel Services Director, University of California, Agriculture and Natural Resources, 300 Lakeside Drive, 6th Floor, Oakland, CA 94612-3550 (510) 987-0096. For information about obtaining this publication, call (800) 994-8849. For information on downloading, call (530) 754-5112.

pr-11/03-SB/CR

ISBN 978-1-60107-296-2

This publication has been anonymously peer reviewed for technical accuracy by University of California scientists and other qualified professionals. This review process was managed by the ANR Associate Editor for Pest Management. 